\title{
International Committee on Systematic Bacteriology Subcommittee on the Taxonomy of Flavobacterium and Cytophaga-Like Bacteria
}

\author{
Minutes of the Meeting, 3 April 1992, Bloemfontein, Republic of South Africa
}

Minute 1. Call to order. A closed meeting was held at 6:55 p.m. on 3 April 1992 in the Lounge, Garden Court Hotel, Bloemfontein, Republic of South Africa. The meeting was called to order by the Chairman, J. Ursing.

Minute 2. Record of attendance. The members present were J.-F. Bernardet, B. Bruun, B. Holmes (Secretary), P. J. Jooste, H. Reichenbach, J. Ursing (Chairman), and E. Yabuuchi.

Minute 3. Approval of agenda. The written agenda was presented and approved. The minutes of the previous meetings which were held on 17 and 20 September 1990 in Osaka, Japan, had been approved by mail and have been published (Int. J. Syst. Bacteriol. 41:460-461, 1991). A copy was given to each member.

Minute 4. Apologies for absence. Apologies were received from R. P. Burchard, K. A. Malik, T. A. McMeekin, W. Reichardt, and $\mathrm{H}$. Wakabayashi for being unable to attend.

Minute 5. Changes in membership and officers. The resignation of R. J. Owen had been received in 1991. The following individuals were elected to full membership: Y. Nakagawa (Tokyo, Japan) and P. Segers (Ghent, Belgium). These elections are subject to approval by the Secretary for the International Committee on Systematic Bacteriology Subcommittees on Taxonomy.

Minute 6. Current membership. The current voting membership of the subcommittee is as follows: J.-F. Bernardet, Jouy-en-Josas, France; B. Bruun, Copenhagen, Denmark; R. P. Burchard, Baltimore, Md.; B. Holmes (Secretary), London, England; P. J. Jooste, Bloemfontein, Republic of South Africa; K. A. Malik, Braunschweig, Germany; T. A. McMeekin, Hobart, Tasmania; W. Reichardt, Kiel, Germany; H. Reichenbach, Braunschweig, Germany; J. Ursing (Chairman), Malmö, Sweden; H. Wakabayashi, Tokyo, Japan; and E. Yabuuchi, Osaka, Japan.

Minute 7. Definition of genera. An urgent need to improve the classification of the various organisms in the group at the genus level had been noted previously. It was reported that, subject to final confirmation, J.-F. Bernardet would be taking up the kind offer of K. Kersters to use the facilities of his laboratory to study the group by rRNA-DNA hybridization or sequencing under the guidance of the subcommittee. P. Segers would be collaborating in the study.

Minute 8. Type strain of Flexibacter maritimus. Following discussions at the previous meeting, the Secretary had undertaken to write a formal article drawing attention to the synonymy of Flexibacter maritimus Wakabayashi, Hikida, and Masumura 1986 and Cytophaga marina Reichenbach 1989; this article has been published (Int. J. Syst. Bacteriol. 42:185, 1992).

Minute 9. Flavobacteriaceae. At the previous meeting, it was noted that the proposed new family name Flavobacteriaceae had not been validated in the International Journal of Systematic Bacteriology. The Secretary agreed to write to the editor of the International Journal of Systematic Bacteriology requesting that the name appear on a forthcoming validation list; this has now been done (Int. J. Syst. Bacteriol. 42:327-329, 1992).

Minute 10. Working group on minimal standards. Some guidance notes on drawing up proposals of minimal standards, drafted by W. Frederiksen and M. Kilian for the Pasteurellaceae subcommittee, were circulated with the agenda. It was decided, however, that these notes would not be adopted in their entirety as a guide for formulating minimal standards for the genus Flavobacterium and Cytophaga-like bacteria. B. Bruun and B. Holmes would continue drawing up a draft list of properties which would be circulated to members.

Minute 11. Second International Symposium. The Second International Symposium on Yellow-Pigmented Gram-Negative Bacteria of the Flavobacterium-Cytophaga Group was held in Bloemfontein, Republic of South Africa, in April 1992 and provided the opportunity for this subcommittee meeting. P. J. Jooste and all those who assisted him were congratulated for organizing such a successful and wellplanned symposium. The intention to publish the proceedings of the symposium was noted.

Minute 12. Flavobacterium aquatile. At the previous meeting it had been accepted that the genus Flavobacterium would ultimately be restricted to the single strain representing this species and to a few other closely related species. Most of the species currently placed in the genus Flavobacterium would thus ultimately be placed in several other genera, including some new genera. For the clinical microbiologists present this had never been the best approach, and B. Holmes (together with R. J. Owen) had previously sought a change in type species to Flavobacterium breve (Int. J. Syst. Bacteriol. 29: $416-426,1979$ ), which, if successful, would have allowed retention of the clinically important species in the genus Flavobacterium. The request was denied (Int. J. Syst. Bacteriol. 32:464 465,1982 ), and at the previous meeting the decision of the Judicial Commission had been accepted with regret. B. Bruun, however, still felt strongly about this issue and asked fellow members to consider the possibility of a fresh request to change the type species. However, a unanimous decision could not be reached as most subcommittee members saw no problem in a change in genus name for the clinically important Flavobacterium species. They did suggest that the clinically most important species, Flavobacterium meningosepticum, should be designated the type species when it is transferred to a new genus as this would prevent any further genus name changes for this organism in the future.

Minute 13. Flavobacterium meningosepticum. The majority of isolates of Flavobacterium meningosepticum show low levels of DNA-DNA relatedness to the type strain so the possibility of requesting a change in the type strain was also discussed; however, the majority of members felt that no action was necessary. It was pointed out that other species also have been found to contain genotypically distinct groups that are phenotypically inseparable. In such cases, it has been recommended that a reference strain should be designated for each genomic species and be deposited in a recognized culture collection. J. Ursing drew attention to a proposal to use the term genomovar (Rosello et al., Syst. Appl. Microbiol. 14:158-164, 1991) in such cases, and all present considered this a good suggestion.

Minute 14. Date of next meeting. The next subcommittee meeting will be held at the next International Union of Microbiological Societies Congress, in Prague, Czechoslovakia, in 1994.

Minute 15. Adjournment. The meeting was adjourned at 8:30 p.m.

Barry Holmes, Secretary 